Kafkasya Calışmaları - Sosyal Bilimler Dergisi / Journal of Caucasian Studies (JOCAS)

Eylül / September 2016, Yıl / Vol. 2, № 3

ISSN 2149-9527 (basılı / print) ISSN 2149-9101 (cevrimici / online)

\title{
Kuzey Kafkasya'da Mevcut ve Potansiyel Etnik Çatışma Alanları
}

Osman Tekir

\begin{abstract}
Özet
Kuzey Kafkasya, tarih boyunca stratejik ve politik açıdan önemini kaybetmeyen ender coğrafi bölgelerden biridir. Karmaşık etnik yapısına rağmen bölgede, burada çıkarı olan büyük güçlere karşı direniş ve mücadele geleneği ortaya çıkmıştır. Sovyetler Birliği'nin dağılmasıyla bölgede doğan boşluğun doldurulması ve tarihsel hesapların yeniden görülmesiyle ilgili hareketlilik başlamışır. Özellikle farklı etnik gruplar arasındaki gerilim ve çatışmalar günümüzde Kuzey Kafkasya'nın temel gündemi olmaya devam etmektedir. Bu gerilim ve çatışmaların nedenlerini ve olası sonuçlarını daha iyi anlayabilmek için önce etnik yapı üzerinde kısaca durulacak, ardından başlıca çatışma alanları ve konuları ele alınacaktır.
\end{abstract}

Anahtar Kelimeler: Kuzey Kafkasya, çatışma, etnisite, etnik şiddet, etnik politikalar

\section{The Current and Potential Ethnic Conflicts in the North Caucasus}

\begin{abstract}
The North Caucasus is an exceptional region which, in terms of economic and political significance, has never lost its importance throughout history. As a result of that significance, the region has witnessed, over the centuries, many struggles against the great powers of the region vying for regional hegemony, despite its internal ethnic diversity. The dissolution of the Soviet Union triggerred conflicts among various groups wanting to fill the power vacuum in the area and settle historical scores. Especially, political tensions and ethnic conflicts among different ethnic groups have become the defining feature of the North Caucasus. To understand the reasons and possible consequences of these processes, first the ethnic structure of the region needs to be analysed. Then, the main areas and subjects of conflict will be studied.
\end{abstract}

Keywords: North Caucasus, conflict, ethnicity, ethnic violence, ethnic politics

* Osman Tekir, Yrd. Doç., İzmir Katip Çelebi Üniversitesi, Siyaset Bilimi ve Kamu Yönetimi Bölümü. 


\section{Etnik Yapı}

Kuzey Kafkasya Rusya'nın güneyinde Kafkas Dağları'yla ve Güney Rusya stepleri arasında kalan bir bölgedir. Dağlar 5642 metrelere kadar yükselip (Elbrus) Kuzey Kafkasya'yı Güney Kafkasya ülkelerinden ayıran doğal bir sınır oluşturur. Bu fiziki coğrafya aynı zamanda bölgenin beşeri coğrafyasıyla ve çoğu etnik gruplar arasında ekonomik, sosyal ve kültürel farklılıkların oluşmasına da sebep olmuştur.

113.000 kilometrekare yüzölçümüne sahip olan bu bölge, coğrafi olarak Rusya yüzölçümünün sadece \% 0.7 'sini oluşturmaktadır. Ancak yüzölçümüyle orantısız şekilde, Sovyet sonrası dönemde Kuzey Kafkasya'da yaşanan gelişmeler hem Rusya hem de bölgedeki diğer ülkelerde çok ciddi askeri, siyasi ve sosyal sonuçlara yol açmıştır ve yol açmaya devam etmektedir (Foxal, 2013:56).

Bölge coğrafi yönden bir bütün olarak görünse de sosyal, kültürel ve hatta tarihsel göstergeler açısından çeşitlilik arz etmektedir. Kafkasya Batı kültürü (Rus kültürü ve Ortodoksluk) ile Doğu kültürü (yerli kültürler ve İslam) arasında sınırların kesiştiği bir nokta olarak düşünülmektedir. Bu bölge medeniyet ve kültür bakımından binlerce yıllık tarihi bir geçmişe sahiptir. Göç yolları ve geçiş noktasında bulunması farklı kültür ve medeniyetlerin mücadele alanı olması için uygun bir zemin hazırlamıştır (Jansız \& Hojaste, 2015). Bu yönüyle Kafkasya, etnik şiddet ve bağımsızlık mücadeleleri konularında yapılan akademik çalışmalar için bir laboratuvar konumundadır (Margaritis, (2010).

Yüzden fazla etnik grubun yaşadığı bir bölge olmasıyla Kafkasya farklı giyim kuşamları, dil ve dinleriyle etnik ve dilsel bir mozaiktir (Coene, 2010: 56). Geçmişte Çarlık Rusyası ve Sovyetler Birliği, günümüzde de Rusya Federasyonu'nun etnik farklılıklar üzerine politikalar üretme çabaları, iskan politikaları ve daha sonra üzerinde durulacağı gibi sınırları yapay olarak çizilmiş olan cumhuriyetlerde oluşturduğu nüfus kombinasyonları, Kuzey Kafkasya'yı adeta "etnik mayın tarlası"na (Erol, 1998) dönüştürmüştür. Üçüncü yüzyılda yaşamış Yunan coğrafyacı Timosthenes, rakam abartılı olarak kabul edilse de Kafkasya'da 300 dilin konuşulduğunu, yine Yunan tarihçi Strabon (MÖ 64-MS 24) 70 farklı etnik grubun yaşadığını iddia etmektedir ki muhtemelen doğrudur. Ortaçağ Arap coğrafyacıları 
Kafkasya'yı "diller dağı" olarak adlandırmaktadırlar (Coene, 2010:56). Paleolitik çağa kadar uzanan Kuzey Kafkasya'daki arkeolojik ve dilsel kanıtlar eski bir kültüre ait büyük bir gövde olduğunu göstermektedir. Bu nüfus muhtemelen, bütün Kafkas halklarının ortaya çıkmasında temel oluşturmuştur. Kuzeybatı, kuzeydoğu ve Güney Kafkasya halkları arasındaki farklılıklar, bu orijinal nüfus üzerine daha sonra gelenlerin kendi kültürel ve dilsel özelliklerini eklemelerinin bir sonucudur (Richmond, 2008:8).

Kafkasya her zaman çok sayıda etnik gruba ev sahipliği yapan dünyanın en ilginç fiziki ve beşeri coğrafyasına sahip bölgelerinden biridir. Halkın ezici çoğunluğu bölgenin yerlisi olmasına rağmen, bölgenin yerel demografik yapısı dış dünya ile kurulan ilişkiler nedeniyle değişime uğramıştır ve uğramaya devam etmektedir. Ayrıca güney ve kuzey kesimleri arasında karşılıklı göçler etnik kimliklerin karışmasına da neden olmaktadır.

19. yüzyılda bölgenin etnik haritası esas olarak Çerkes, Abaza, Abhaz, Karaçay, Balkar, Oset, Çeçen, İnguş ve Dağıstanlı (Avar, Lezgi, Dargi, Agul vd.) halklarından oluşuyordu. Yunanlılar Homeros zamanında (9. yüzyıl) Batı'dan geldiler. İlk Yahudi göçü 7. yüzyılda gerçekleşti. Bugün azımsanmayacak bir nüfus yoğunluğuna sahip olan Türkler, 3. yüzyıldan itibaren kuzeyden gelmeye başladılar.

Ruslar gönüllü veya zorunlu olarak 16 . yüzyılda Kafkasya'ya ilgi duymaya başladıktan sonra, bir hükümet ve devlet politikası olarak silah zoruyla bölgede var olma çabası içine girdiler. Günümüz Kafkasya'sında etnik durum, Sovyetler Birliği döneminde oluşan karaborsa ekonomisi, bürokratik burjuvazi ve mafya, ardından da perestroyka süreci, Sovyetler'in dağılması, yerel ve bölgesel politikalardaki yetersizlikler, totaliter rejimlerin yeniden canlandırılma isteği ve etnik sorunların ve gerilimlerin askeri güçlerle çözümlenmesi teşebbüslerinden etkilenmiştir (Guseynov, 2012).

Etnik çeşitliliğe rağmen, özellikle Kafkasya'nın yerli halkları arasında İslam'la birlikte etnisiteyi aşan bölgesel bir bilinç, din ve etnik olarak üç katmanlı bir kimliğe sahiptir (Bugajski, 2014:27). Kuzey Kafkasya, Moskova yönetimine karşı direnişin sembolü olarak bölgenin ayrılmaz bir parçasıdır. Rusya'ya karşı direnişte bulunan Kafkas halklarının, (son zamanlarda çok sık yapıldığı gibi) motivasyonlarının sadece dini radikalizme indirgenmesi, buradaki 
milliyetçi uyanışı ve Rus sömürgeciliğine karşı direnişi gölgeleme amacını taşımaktadır. Moskova, bölgedeki istikrarsızlığı ve karmaşayı uluslararası alanda kışkırtma ve İslami radikalizmle mücadele kılıfı altında küçümsemek, itibarsızlaştırmak ve gözden kaçırmak istemektedir. Ancak çatışmalar, yakın zamana kadar sakin olan bölgelere yayılmakta, genişleyerek derinleşmektedir. Bölgede İslam'ın gelişmesi istikrarsızlığın görünürdeki kaynağı olarak gösterilse de çözümlenmemiş gerilimler ve çoklu etnik yapılar, sosyal sorunlar, Rusya ile entegrasyonda yaşanan zorluklar bu istikrarsızlığı besleyen unsurlardır. Günümüzde bile Rusya Federasyonu'nun diğer bölgelerinde birçok Kuzey Kafkasyalının yaşadığı göz önünde bulundurulduğunda; farklılık, istikrarsızlık ve sadakat yetersizliği görülecektir. Bölgedeki çoğu yerleşimciler, ayrımcılık, yabancı düşmanlığı ve yabancılaşma hissetmektedir (International Crisis Group Working to Prevent Conflict Worldwide, 2012).

Sovyetler Birliği döneminde özerk cumhuriyetlerin kurulması etnisite ve toprak arasındaki bağı güçlendirmiştir. Örneğin Dağıstan hiçbir grubun tek başına diğerleri üzerinde hakimiyet kuramadığı ilginç bir ülkedir. 1980 'lerin sonlarında etnik mağduriyetler yaşamış farklı Kafkas halkları arasındaki uzun süre bastırılmış rekabetler, çekişmeler ortaya çıkmıştır. Üzerinde durulması gereken önemli nokta ise Sovyetler Birliği'nin dağılmasından bu yana, çözüldüğü düşünülen sorunların aynı gündemle yeniden ortaya çıkmasıdır. Bölgedeki tarihsel rekabetin merkezinde toprak ve ülkeyle ilgili kimliklerinin erozyona uğratılmasının yanında, iş fırsatları, federal yatırımların dağılımına erişim gibi çağdaş dünyanın ve modern siyasetin ilkeleriyle ilgili konular vardır (Matveeva, 2012:5). Rusya Federasyonu'nun geri kalanının aksine bireyin sosyal statüsü, iddiaların kabul edilebilir bir düzeyde olması, idari ve ekonomik kaynaklara erişimin tanımlanmasında etnisite güçlü bir siyasi kategori olarak ortaya çıkmıştır. Örneğin Dağıstan'da toprak zenginliği ve siyasi gücün Lezgi, Kumuk, Dargi ve nüfusça en kalabalık halk olan Avarlar arasında paylaşılması, diğer etnik unsurlarla sürtüşmeyi arttıran sebeplerden biri olmuştur (Erol, 1998).

Etnik ve alt etnik bağlantıların güçlü olması, güçlü etnik özellikler taşımak, etkili sosyal ilişkiler, güce ve kaynağa daha kolay erişime işaret eder. Kuzey Osetya, Kabardey-Balkar ve Dağıstan gibi çoklu 
etnik yapıya sahip cumhuriyetlerde etnik ilişkilerde çok önemli boyutlarda bir sorun yaşanmamaktadır. Tam tersine günlük hayatta farklı etnik gruplar arasında kültür etkileşimi geniş ölçüde korunmuştur. Etnik gerginliklerin temelinde göç ve toprak sorunları vardır ve bu gruplar arasındaki ilişkiler, kendilerine uygun yerler verildiğinde uyumlu görünmektedir (Matveeva, 2012: 20).

Buna rağmen etnik gruplar arasındaki sorunlar her zaman kolayca tespit ve teşhis edilememektedir. Her şeyden önce, ayrımcılığı önlemek ve ayrımcılığa maruz kalmamak için, bazı insanlar kendilerini çoğunluk nüfusa ait olarak görmeyi tercih etmektedirler. Dağlarda yaşayan insanlardan ovalara taşınan birçok etnik unsur vardır. Kişinin etnik ve ulusal kimliğinin korunması Kafkasya'da çok önemli bir konudur ve bu, Andi ve Dido gibi nüfusça küçük etnik grupların genç nesilleri için çok daha büyük önem taşır. Sovyet kültürünün giyim, ev eşyası gibi çeşitli unsurları bölgede olmasına rağmen, bölgesel izolasyon, yabancı etkilerinin sınırlı kalmasına ve dillerini korumasına yardımcı olmuştur. Yolların ve kentlerin inşası, Ruslaştırma, İslam karşıtlığı, zorla kolektifleştirme ve siyasi baskılar, bu bölgeleri daha savunmasız hale getirmiştir. Karma evliliklerin artması ve eğitim standartlarının yükselmesi kimlik erozyonuna katkıda bulunmaktadır. Ancak, uygulanan Sovyet ve Rus politikalarına duyulan tepki Kuzey Kafkas halkları arasında milli kimlik duygularının yükselmesine ve Ruslara karşı nefretin artması gibi ters bir etkide de bulunmaktadır (Coene, 2010:57).

Kuzey Kafkasya'nın etnik ve dilsel haritası başlı başına özgün bir çalışma alanıdır ve özlü ve anlaşılır bir şekilde ana hatlarını çizmek zordur. Buna rağmen, günümüz Kafkasya siyasetini anlamak ve gelecek hakkında öngörülerde bulunabilmek için, etnik-dilsel ve dini koşullar hakkında bilgi sahibi olmak çok önemlidir. Çünkü, özellikle Sovyetler Birliği'nin dağılmasından sonra ortaya çıkan istikrarsızlık çok farklı konulardan kaynaklansa da etnik unsur bir kaldıraç görevi görmektedir. Güney Kafkasya'yı anlamak nispeten kolaydır; Azeriler (9.5 milyon), Gürcüler (4 milyon) ve Ermenilerin (3.5 milyon) yanı sıra nüfusu az bir kaç etnik grup daha olmak üzere üç ana halktan oluşmaktadır. Dolayısıyla Güney Kafkasya'daki ülkeler arasındaki temel anlaşmazlık konuları ve çözüm yolları daha spesifik ve belirgin bir nitelik taşımaktadır. Bu nedenle gerek iç siyaset gerekse de bu 
ülkeler üzerinde dış ülkelerin uygulayacağı siyaset belli formlar içerebilir. Ancak Kuzey Kafkasya'daki etnik gerginlikler ve çözüm yollarının çok daha karmaşık bir nitelik taşıması, bu karmaşıklığın ortaya çıkmasına sebep olan Çarlık Rusyası, Sovyetler Birliği ve 1990 sonrası Rusya Federasyonu politikalarını analiz etmeyi gerektirmektedir.

\section{Rusya'nın Kuzey Kafkasya Üzerindeki Etnik Politikaları}

Rusya'nın Kuzey Kafkasya'ya girişi, 16. yüzyılda, Altın Orda devletinin dağılması sırasında, 1539 yılında Kazan'ın Korkunç Ivan'ın fethiyle başlamıştır. Kafkasya'nın aniden Rus İmparatorluğuyla ilgili bir nesne haline gelmesi, diğer güç merkezlerinin ilgisini arttırmıştır. Rusya'nın güneye inme ilgisinin arkasında, sıcak sulara ve İran pazarına erişmek gibi bir arayış yatıyordu. Bunun arkasında, sıcak denizlere ve Güney Hindistan'a doğru imparatorluğun genişlemesi hayalini gerçekleştirmenin yanında, Güney Asya'nın sınırlarında İngiltere ve Rusya arasındaki "Büyük Oyun" yatıyordu (Cornell, 2001:12).

Kuzey Kafkasya ülkelerinin durumunun temel bir belirleyicisi olan birbirleri ve komşuları ile ilişkileri, Çarlık Rusyası, Sovyet ve Rusya yönetimlerinin bir mirası niteliğindedir. 19. yüzyılın ortalarından itibaren Kafkasya'nın ana belirleyici faktörü Rusya ve yöneticilerinin politikaları olmuştur. Bölgenin bazı kısımları uzun süreden beri Rus kontrolü altındadır. Örneğin 1990'lı yıllardan beri Kafkasya'da yaşanan çatışmaların en bilineni, Çeçenistan'ın bağımsızlığını kazanmak için Çeçenlerin haklı olarak (Central Eurasia Standard, 2014) Ruslarla yaptığı iki savaştır. Bugünkü İslami karakterli isyanın temelinde bunun yatmasının ve Çeçen savaşlarının yarattığı yıkımın ardından istikrarsızığın yayılması bu nedenledir. Rusya'nın karşı karşıya kaldığı en kötü güvenlik krizi bu savaşların ertesinde ortaya çıkmıştır. Eğer Rusya Çeçenistan ve Dağıstan'da kaybederse (her ne kadar Rus yetkililer bunun yanlış bir algılama olduğunu ifade etseler de) bir domino etkisi yaratacağı ifade edilmektedir. Domino teorisine göre, bir cumhuriyet federasyondan ayrılırsa, diğer etnik grupların ayrılmasının yolunun açılmasına neden olabileceği ile ilgili yaklaşımdır (Koehn, 2011). Bu nedenle, Yeltsin döneminde Rusya'nın Kuzey Kafkasya'ya yaklaşımı, Rusya Federasyonu ile bağımsızlık taleplerinin yaratabileceği "domino etkisi" nedeniyle mesafeli olmuştur (Matveeva, 2012: 6). 
Ancak, Kuzey Kafkasya, Rus halkını ve Sovyet sonrası Rusya'nın sorunlarını inceleyen analistler için önemli bir çalışma alanıdır. Daha önce Kuzey Kafkasya'da yaşanan gelişmelere öncelikle etnik gruplar arası ilişkiler ve bölgesel politikalar açısından bakılırken; günümüzde bu konu Rusya ölçeğinde ele alınmaya başlanmıştır. Çeçenistan, Inguşetya ve Dağıstan bu konuda tek başına değildir. Rusya'nın diğer bölgelerinin de bu bölgeleri nasıl algıladığı önem kazanmaya başlamıştır (Markedonov, 2013).

1990'larda bağımsızlık için Rusya ile savaş yaşayan Çeçenistan, 1859 'dan bu yana Rusya'nın kontrolü altındadır. Batı'daki Çerkes cephesinin çöküşüyle birlikte Kuzey Kafkasya'nın tamamı 1864'den itibaren Rusya kontrolüne girmiştir. O tarihten sonra Rusya'nın Kuzey Kafkasya üzerindeki etnik politikaları uygulamaya konuldu. Özellikle 1921 ve 1991 yılları arasındaki Sovyet döneminde gerçekleşen politikalar çok önemlidir. Burada dikkat edilmesi gereken nokta Lenin'in milliyetler politikası ve Kafkasya'nın sınırlarının yeniden çizilmesidir ki, günümüzdeki etnik gerilim ve çatışmaların kaynağını bu politikalar oluşturmuştur. Sovyetler Birliği'nin azınlık gruplar için "otonomi" kavramı üzerinden yarattığı federal yetki paylaşımı mekanizmasıyla cumhuriyetler ve bölgeler arasında doğrudan uyguladığı "bölme" siyaseti, Birliğin totaliter yönetiminin bir aracı olmuştur (Cornell, 2001: 10). Bunu takiben, Sovyetler Birliği'nin dağılmasından sonra Rusya Federasyonu özgün bir Bağımsız Devletler Topluluğu'nu yeniden inşa etmekten çok "ortak ev" olarak adlandırdığı Kafkas ülkelerini, çok iyi bildiği tarihsel stratejisini, "böl ve yönet" politikasını, uygulamaya başlamıştır. Bu politikaya göre, Rusya önce çatışmaları körüklemekte, daha sonra çatışmalara müdahale ederek tarafları barış içinde tutabilecek yegane güç olarak ortaya çıkmaktadır (Khanna, 2011: 94).

Rusya'nın böl-yönet politikası bütün Kafkasya üzerinde uygulama alanı bulmakla birlikte, güvenlik sorunlarının çokça yaşandığı bölgelerde, etnik sorunların, dolayısıyla etnik bilincin üst düzeyde olduğu bölgelerde ağırlıklı olarak hissedilmektedir. Bu durum cumhuriyetten cumhuriyete değişmekle birlikte, bir cumhuriyet içerisinde bölgeden bölgeye göre de değişiklik göstermektedir (Dulayev \& Savin, 2012). Rusya, Kafkas halkları arasındaki her türlü farklııkları kullanarak Kuzey Kafkasya'yı elinde tutma çabası içindedir. 
Örneğin, 15 Mayıs 2016 tarihinde Rus Ortodoks patriği tarihte ilk defa Kabardey-Balkar Cumhuriyeti'nin başkenti Nalçik'i ziyaret etmiş ve Mariya Magdalina Katedrali'nde bir ayin düzenlemiştir. Rus Ortodoks Kilisesi'nin Nalçik'teki katedrali ziyaretini ilginç kılan bazı unsurlar vardır ki, kökeni 500 yıl öncesine dayanmaktadır. Çar Korkunç İvan'ın ikinci eşi Mariya Temryukovna Mariya Magdalina Katedrali'nin doğal koruyucusu olarak kabul edilmektedir. Mariya Temryukovna, Çerkes asıllı Goşeney'in (Rus kaynaklarında Kuçeney) Korkunç İvan'la evlenmesi ve Hıristiyanlığı kabul etmesinden sonra aldığı addır.

Günümüz Kafkasya'sında dağınık halde bulunan Çerkesler, Adıgey, Kabardey-Balkar ve Karaçay-Çerkes cumhuriyetleri başta olmak üzere Çerkeslerin yaşadığı bölgelerin yeniden birleşmesi için çağrıda bulunmaktadırlar. Dünya Çerkes Birliği (DÇB) bu amaçla kurulmuştur (Bugajski, 2014:28). Rusya yaklaşık 500 yıl önce Korkunç İvan ile Çerkes prensesi Goşeney arasındaki evliliği "Çerkeslerin Rusya'ya gönüllü katılımı" olarak değerlendirerek, Çerkes topraklarının fetih tarihiyle ilgili yeni algılar yaratmaya çalışmaktadır. Bu nedenle de, Çerkeslerin "Rusya'ya katılımı"nın 460. yıldönümü olan 2017 yılında büyük bir kutlama hazırlığı yapmaktadır. Bu ziyareti önemli kılan bir başka etken de, diğer Kafkas cumhuriyetlerinin çoğunun aksine Kabardey-Balkar nüfusunun yaklaşık \% 20'sinin Ortodoks Hıristiyan olması nedeniyle, Hristiyanların cumhuriyette önemli bir azınlık olmasıdır. Böylece Patrik Kiril'in Kabardey bölgesini ziyaretinin aynı zamanda, Kuzey Osetya'nın Mozdok şehrinde yaşayan az sayıdaki Hıristiyan Çerkesle Müslüman Çerkesler arasında bir ayrılık yaratma amacı taşıdığı dile getirilmektedir (Dzutsati, "Moscow Uses....", 2016). Çünkü özellikle son yirmi yılda Kuzey Kafkasya'da Çeçenistan ve Dağıstan dışında, Çerkeslerin yaşadığı kuzeybatı bölgesindeki sorunlar da önemli bir sorun olarak ortaya çıkmıştır. Çerkesler farklı cumhuriyetlerde ve "bölgesel-idari birimler"de dağınık olarak kalmışlardır. 1864'te sona eren "Kafkas Savaşları"ndan beri bölge içinde dağıtılan ve Osmanlı topraklarına sürgün edilen Çerkeslerin anavatanlarına dönüşleriyle ilgili bir prosedür bulunmamaktadır (Grebennikov, 2015). Böyle bir prosedürün var olması ve 1864 sürgününden sonra başta Türkiye ve Ortadoğu ülkeleri olmak üzere dünyanın çeşitli yerlerindeki Çerkeslere dönüş yolunun açılması 
Rusya açısından arzu edilmeyen sonuçlar doğuracağından, bu sürecin önünde bazı engeller oluşturulmaktadır.

Günümüzde, Kuzey Kafkasya'da sosyal, ekonomik, etnik ve politik zıtlıkları tespit edecek herhangi bir objektif sistem yoktur. Uzun yıllardır Rus yönetimi altında bulunmalarından dolayı etkisizleştirilen Kafkas halkları ve yönetimlerinin yanında, geleneksel etnik politikaları uygulayarak Kuzey Kafkasya üzerindeki egemenliğini devam ettirme çabası içinde olan Rusya açısından da bölgede sosyal, ekonomik ve politik zıtlıkları tespit edecek herhangi bir objektif sistem yoktur (Panin \& Tikunov, 2015: 78). Çünkü, son yıllarda Kuzey Kafkasya'daki Rus nüfusun bölgeyi terk etmeye başladığı, Kuzey Kafkasya'dan ayrılan Rusların Moskova'daki yetkililer arasında da endişe oluşturduğu bilinmektedir (Goble, "Non Russian....", 2015). Çünkü, Kuzey Kafkasya'daki diğer etnik gruplar üzerinde Rus kontrolünün sağlanması ve Rus olmayan cumhuriyetlerin Rusya Federasyonu'na bağlanmasında Rus nüfusun önemli bir işlev gördüğü tarihsel süreçte kanıtlanmıştır.

Rus nüfusun son yıllarda Kuzey Kafkasya'dan ayrılmasının sebepleri üzerinde birçok araştırma mevcuttur. Kabardey-Balkar Cumhuriyeti'ndeki Nalçik Enstitüsü'nden Natalya Varivoda, 1960'ların başlarına kadar (Sovyet dönemi) Kuzey Kafkasya cumhuriyetlerindeki Rus nüfusun sayısı ve oranı artarken, bu tarihten sonra azalmaya başladığını ve 1990 'larda resmi Rus istatistiklerinden daha yüksek oranda kesin ve göreceli olarak düştüğünü, bölgenin çoğu cumhuriyetlerinde hem kentsel hem de kırsal alanlarda düşmeye devam ettiğini ileri sürmektedir (Goble, "Ethnic Russian.....", 2015).

Sovyetlerin çöküşüyle, etnosentrik hareketler artmaya başlamıştır. Ekonomik şartların kötüleşmesi, kanun hakimiyetinin bozulmasıyla bazı etnik anlaşmazlıklar daha da artmış ve politik mücadelede yeni elitler ortaya çıkmıştır. 1990'ların başında etnik unsurların kendi kaderlerini tayin kavramı egemen olmuştur. Çünkü onlar yerli, bastırılmış, yurtlarından sınır dışı edilmişlerdi ve evvelce sahip oldukları topraklar üzerinde hak iddia ediyorlardı. Buna ilaveten hak iddia ettikleri toprakların sınırları, etnik sınırlarla örtüşmüyordu. Ayrıca bazı etnik gruplar başka cumhuriyetlerde azınlık durumunda kalmışlardı ve bunların hiçbir ulusal hakları yoktu. Bazı etnik grupların, zulüm ve ayrımcılık yapıldığıyla ilgili şikayetleri vardı. 
Dolayısıyla toprak, etnik milliyetçilik ve politik tartışmalar ve çatışmalar artmıştır (Bugajski, 2014:28). Rusya'nın bu çatışmalar nedeniyle bölge üzerindeki etkisinin azalmaya başlamasıyla birlikte, etnik Ruslar devletinin varlığını hissedemediklerinden, kişisel güvenlikleriyle ilgili duydukları korku, suçlardaki artış ve Rusya Federasyonu'nun başka yerlerindeki aile üyeleriyle bağların kopmasından duydukları endişe nedeniyle Kuzey Kafkasya'yı terk etmektedirler (Goble, “Ethnic Russians.....", 2015).

Çalışmamızın bu bölümünde Sovyetlerin dağılmasından sonra yükselen etnik bilincin de etkisiyle ortaya çıkan çatışma ve anlaşmazlıklar ele alınmaya çalışılacaktır. Bu anlaşmazlıklar ve çatışmaların otonom cumhuriyetler temelinde ele alınması, konunun daha iyi anlaşılmasına yardımcı olacağından, mevcut ve potansiyel çatışma alanları temelinde ele alınması uygun olacaktır. Etnik gerilimlerin en yoğun yaşandığı Karaçay-Çerkes, Kabardey-Balkar, Kuzey Osetya (İnguş-Oset ekseninde), Çeçenistan ve Dağıstan, üzerinde durulacak cumhuriyetlerdir. Adıgey Cumhuriyeti'ndeki "Çerkes Sorunu" bu çalışmada irdelenmeyecektir.

\section{Kuzey Kafkasya'da Etnik Çatışma Alanları ve Konuları}

Kafkasya, Sovyetler Birliği'nin dağılmasını izleyen çeyrek asırda "yeni dünya düzensizliği" olarak adlandırılan süreçten (Cornell, 2001:1) Avrasya kıtasının en fazla etkilenen bölgelerinden biri olmuştur. Eski Sovyetler Birliği topraklarında meydana gelen silahlı sivil çatışma örneklerinden birçoğu Kafkasya'da meydana gelmiştir. Bu savaşların ilk örneği olarak Çeçenistan savaşı verilebilir. Tarihsel olarak Kuzey Kafkasya, Osmanlı İmparatorluğu (bugünkü Türkiye), Pers İmparatorluğu (bugünkü İran) ve Rus Çarlığı (bugünkü Rusya Federasyonu) gibi bölgenin büyük güçlerinin buluşma noktasıdır. 16. yüzyılın ortalarından itibaren bölgeye ilgi duymaya başlayan Rusya, kendisini bölgenin yerleşimcileri ile sürekli karmaşık bir çatışma içinde buldu (Central Eurasia Standard, 2014). Özellikle 1990 sonrası Çeçen savaşları ve bu savaşların ortaya çıkardığı zulüm ve yıkım, bölgede mevcut diğer rahatsızlıkların dile getirilmesine sebep olmuştur ki, bölge bu yönüyle açık bir çatışmaya dönme potansiyeline sahiptir. Sovyetler Birliği döneminde uygulanan siyasal sistemin bölgeleri ve milliyetleri nispeten kontrol edebilmesinden 
dolayı düşük yoğunluklu olarak devam eden "dondurulmuş çatışmalar", Sovyetler Birliği'nin dağılmasından sonra mevcut rahatsızlıklarıyla su yüzüne çıkmıştır.

Kuzey Kafkasya'daki mevcut olan gerilimin kaynaklarından birinin etnik grupların yaşadığı bölgeler arasındaki sınır anlaşmazlıkları olduğu bilinmektedir. Bu sınırlar, herhangi bir etnik ve tarihi gerçeklik göz önünde bulundurulmadan özellikle gerilim ve çatışma kaynağı oluşturması için kasıtlı olarak belirlenmiştir (Tekir, 2011: 62). Bunun yanında etnik üstünlük, etno-fobi ve diğer etnik gruplara karşı çeşitli nedenlerle beslenen düşmanlık duyguları etnik gerilimleri arttıran ana kaynaklardır.

\section{Karaçay-Çerkes Cumhuriyeti}

Karaçay-Çerkes Cumhuriyeti'nin 500.000'e yakın nüfusu dört ana yerli grup ve önemli bir Rus azınlıktan oluşmaktadır. 2010 yılı nüfus sayımı rakamlarına göre Karaçaylar, Kabardey-Balkar Cumhuriyeti'ndeki komşuları Balkarlar gibi Türkçe konuşan ve toplam nüfusun \% 41'ini (195.000 kişi) oluşturan çoğunluk etnik gruptur. Ruslar \% 31.6 oranla (150.000 kişi) ikinci sıradadırlar. Çerkes nüfus ise \% 12 oran (57.000 kişi), Çerkeslerle yakın akraba olan Abazalar \% 7.8 (37.000 kişi) ve Türki bir dil konuşan bir diğer grup Nogaylar ise \% 3.3 oranla (16.000 kişi) Karaçay-Çerkes Cumhuriyeti'nin beşeri coğrafyasını oluşturmaktadırlar (Bugajski, 2014: 30).

Karaçay-Çerkes, Kafkasya'nın diğer bölgelerinde İslamcı şiddetin ve Çeçenistan kaynaklı sorunların daha az yaşandığı bir cumhuriyettir. Ancak çoğunlukla iç istikrarsızlıkla ilgili sorunları vardır. Diğer cumhuriyetlerde olduğu gibi, özellikle toplumu oluşturan iki ana grupta, Karaçaylar ve Çerkesler arasında gerginlikler vardır.

Karaçay-Çerkes, federal bütçeden büyük oranda yardım alan ve genel anlamda ekonomisi tarım, hayvancılık ve dağ turizmine dayalı olan bir cumhuriyettir. Nüfusun önemli bir kısmının hayvancılıkla uğraşması meralara olan talebin artmasına ve giderek siyasal bir konu haline gelmesine neden olmuştur. Günümüze kadar cumhuriyet içerisindeki toprakların yeniden dağıtımı, Karaçay-Çerkes Cumhuriyeti'ndeki etnik ve siyasi çatışmaların artmasına neden olmaktadır (Liono, 2000).

Çerkesler, nüfusun çoğunluğu Karaçay ve Rus olduğu için temsilde 
adalet ve kaynaklara erişimdeki engellerden şikayet etmektedir. Karaçay ve Çerkesler cumhuriyet hükümetinde temsil konusunda çatışma içindedirler. Ayrıca, onlar iki komşu cumhuriyette de yaşamaktadırlar. Balkarlar, Kabardey-Balkar'da; Karaçaylar, KaraçayÇerkes'de yaşamaktadır. Etnik Balkarlar, Kabardey-Balkar'da 900.000 olan toplam nüfusun \% 13'ün altında bir oranla azınlık oluştururken; Karaçaylar, 500.000 civarında olan toplam nüfusun yaklaşık \% 41 gibi bir oranla, cumhuriyetteki en büyük etnik gruptur. Etnik Çerkesler, Kabardey-Balkar'da \%57 çoğunluğa sahipken; Karaçay-Çerkes'de \% 12 'lik oranla azınlık durumundadırlar. Yani Karaçay-Çerkes ve Kabardey-Balkar cumhuriyetleri neredeyse birbirlerinin aynasıdır (Dzutsati, 2013). Eğer Karaçay-Çerkes ve Kabardey-Balkar arasında stratejik bir sınır değişimi söz konusu olursa, hem Türkçe konuşan etnik grubun, hem de Çerkeslerin birlikte yaşayabileceği bir devletleri olacaktır. Karaçay-Çerkes ve Kabardey-Balkar cumhuriyetleri 1920 'lerden bu tarafa Rusya Federasyonu içinde iki özerk birime ayrımış olarak yaşamaktadırlar. Çerkesler genelde kuzeyde, Karaçay ve Balkarlar ise her iki cumhuriyetin güney dağlarında yaşamaktadırlar. Bu nedenle örneğin Karaçay-Balkar ve Kabardey-Çerkes özerk cumhuriyetleri oluşturulmuş olsa iki etnik homojen grup bir araya getirilmiş ve bu anlamda daha istikrarlı birimler oluşturulmuş olurdu. Bunun yerine, Stalin "böl-yönet" politikaları doğrultusunda iki etnik gruptan oluşan heterojen birimler oluşturmayı uygun gördü. Bu da doğal olarak gelecek için sorunlar yarattı (Cornell, 2001: 253).

Kuzey Kafkasya'daki Çerkes nüfusu 19. Yüzyılda Rus ordusu tarafından kırıldı, sürgün edildi ve anavatanlarında kalanların denize erişimi engellendi ve stratejik bakımdan önemli Karadeniz kıyılarından izole edildiler. Karaçay ve Balkarlar ise Stalin rejimi tarafından İkinci Dünya Savaşı sırasında topluca sürgün edildiler ve ancak 1957 yılında anavatanlarına dönmelerine izin verildi (Dzutsati, 2013). Bu nedenle, Rusya'nın gerginlik ve çatışmalar üzerinden kontrolü sağlamak için uyguladığı "böl-yönet" politikası uyarınca, yakın zamanlarda homojen toplumların oluşmasına rıza göstermeyeceği kuvvetle muhtemeldir.

Karaçay-Çerkes'de etnik ilişkiler, resmi görevlere etkin kişilerin atanması ve seçimlerde etnik rekabet üzerinden devam etmektedir. Çoğunluktaki Karaçay ve azınlık Çerkes nüfusu arasındaki ilişkiler, Çerkeslerin Karaçaylar tarafından marjinal hale getirildiği iddiası ile 
2005 yılında iyice kötüleşmiştir. Haziran 2005'de Karaçay-Çerkes Cumhuriyeti'nin diğer küçük azınlığı Abazalar, sınırların belirlenmesinde kendilerinin dikkate alınmadığı ve topraklarının elinden alınması intimali olduğunu öne sürerek cumhuriyetin parlamento binasını işgal etti. Abazalar, toprak ve tarımsal alanlardan yoksun kaldıklarında, şehirlere göçün teşvik edileceği ve büyük bir asimilasyon riski altında olacaklarından endişe duymaktadırlar (Minority Rights Group International, 2014). Azınlık gruplarının asimilasyon endişesi taşıması ve bu uğurda mücadele etmeleri Kuzey Kafkasya yerlilerinin taşıdıkları etnik bilinç açısından dikkate değer bir durumdur.

17 Mart 2016'da çeşitli Çerkes örgütleri Kabardey-Balkar ve Karaçay-Çerkes cumhuriyetlerinde, bölgesel düzeyde yeni bir bağımsız örgüt kurma planlarını açıkladıktan sonra, Karaçay-Çerkes yönetimi, böyle bir planın gerçekleştirilmesinin Adige Khase adlı köklü Çerkes örgütünün kapatılmasıyla aynı anlama geleceğini ifade etti. Çerkes eylemcilere göre Karaçay-Çerkes yönetimi Çerkes örgütlerine baskı uygulamaktadır (Dzutsati, Circassian Propose..., 2016).

Gerek Karaçayların gerekse de Çerkeslerin kendi aralarında birlik oluşturma fikri etnik bilinci körüklemekte, etnik bilinç arttıkça etnik gruplaşmalar çoğalmakta; sonuçta aynı cumhuriyet içinde farklı görüşler belirmekte, daha da ileri gidilerek kendi bağımsızlıklarını ilan etmekte ve etnik çatışmalar yaşanmaktadır. Bugün için her ne kadar çatışmaların savaşa dönme intimali olmasa da etnik gerilim bölgedeki diğer cumhuriyetleri de etkileyerek bölgeyi derinden etkileme potansiyeline sahiptir (Yasa, 2008).

\section{İnguş-Oset Gerilimi}

Sovyetler Birliği'nin kurulmasının ardından 1944-1957 yılları arasında toplu halde Orta Asya'ya sürgüne gönderilen ve topraklarının bir kısmı komşuları arasında paylaştııılan İnguşlar 1992 yılına kadar Çeçen-inguş Özerk Cumhuriyeti'nin parçası olarak SSCB içinde yer aldılar. 1991 yılında Çeçen-İnguş Cumhuriyet Meclisi bağımsızlığını ilan etmesine rağmen, Çeçenlerin aksine İnguşlar Rusya'dan ayrılmak istemedi ve bu durum 1992 yılında gerçekleşen halkoylamasıyla resmiyet kazanarak Inguşetya Cumhuriyeti kuruldu (Coene, 2010: 
48). Ancak ortak sınırlarının tam olarak belirlenmemiş olması Çeçenlerle İnguşlar arasındaki gerilime katkıda bulunmuştur. íkinci Dünya savaşı sırasında Stalin'in İnguşları sürgüne göndermesi, 1957 yılında Kruşcev'in affıyla anavatanlarına dönmeleri, ancak topraklarının Osetlere verildiğini görmeleriyle birlikte İnguş-Oset gerilimi başlamış oldu (Nichol, 2010).

Bugün İnguşetya'nın nüfusu 412.500 olup; bunun 385.500 'üni İnguşlar (\%94.1), 18.765'ini de \%4.6) Çeçenler oluşturmaktadır.

Kuzey Osetya-Alanya Cumhuriyeti ise 713.000 nüfusa sahiptir ve \% 65.1 oranda Oset çoğunluğu vardır. İkinci sıradaki etnik unsur \% 20.8 ile (147.000) Ruslar iken; İnguş nüfus sadece 28.000 civarındadır ve toplam nüfusun \% 4'ünü oluşturmaktadır. Kuzey Osetya, Kuzey Kafkasya coğrafyasının orta yerindedir. Küçük bir toprağa sahip olmasına rağmen $(8.000 \mathrm{~km} 2)$ kuzeydeki ovalardan dağ sıralarına kadar büyük bir coğrafi çeşitlilik gösterir. Rusya'da nüfusun en yoğun olduğu bölgelerden biridir. Cumhuriyetin \%40'ını oluşturan dağlık kesimlerdeki yerleşim azdır ve bu bölgelerde sadece 8.000 insan yaşamaktadır. Nüfusun neredeyse 2/3'ü şehirlerde yaşamaktadır (Dulayev \& Savin, 2012).

Kuzey Kafkasya'daki Oset-inguş gerilimi Sovyet sonrası dönemde bölgesel özerkliğe sahip iki etnik grubun açık savaş haline dönüştüğü tek örnektir. İki etnik grubun kültürel bakımdan uyumsuz oldukları yönünde tartışmalar da bulunmaktadır. Gerçekten de, İnguşlar Çeçen diline akraba bir dil konuşurken; Osetler, bir Doğu İran dilini konuşmakta ve Alan soyundan olduklarına inanılmaktadır (Rezvani, 2010:423).

Oset-Inguş çatışması ise bir toprak gerilimi üzerine inşa edilmiştir (Bugajski, 2014: 35). Eylül 1989'da, İnguş halkının ikinci kongresi Grozni'de toplandı ve 1944 yılından önce, yani İnguşların sürgüne gönderilmelerinden önce kendilerine ait olan Prigorodny rayonunun, Çeçen-inguş cumhuriyetinin bir parçası olduğu, İnguş toprak bütünlüğünden ayrılamayacağı ve yeniden İnguş topraklarına dahil edilmesi konusu onaylandı. Ancak, Kuzey Osetya liderliği herhangi bir toprak iadesine karşı olduklarını dile getirince gerilim yükseldi. Ancak Çeçen-İnguş birlikteliği General Dudayev'in liderliğinde Çeçenlerinin domine ettiği bir Sovyet karşıtı bir kampanyaya dönüştü. Hal böyle olunca İnguşlar bağımsızlık iddialarından uzak durmaya gayret ettiler. 
Bunun iki nedeni vardı: Birincisi, bağımsız bir Çeçen devletinin tanınma korkusu ve Zagayev hükümetinin değişmesinden sonra gerçekleşen Çeçen kongrelerinde temsil imkanı bulamamaları, ikincisi de, Moskova ile iyi ilişkilerin sürdürülmesi durumunda Prigorodny'nin geri kazanılması umuduydu (Cornell, 2001: 244).

Çeçen ve İnguşların 1957 yılında doğdukları topraklara dönmelerine izin verilmesine rağmen; Prigorodny rayonu Kuzey Osetya'nın kontrolü altında kalmaya devam etti. 1973 ve 1980 yılları arasında İnguşlar, İnguşetya ile Prigorodny rayonunun yeniden birleşmesi taleplerini dile getirdiler ve Grozni'de çeşitli gösteriler ve mitingler ve gösteriler düzenlediler. 1991 yılının başlarında gerilim yükseldi ve yavaş yavaş etnik şiddete dönüştü (Askerov, 2015:91). İnguşlar, aslında kendilerine ait olan bu toprakların geri alınmasını "tarihsel adaletin temin edilmesi" (Dudley, 2012) olarak gördüler.

Karşıııkı gerilim devam ettikten sonra, Oset-İnguş çatışması 1992 yılında Kuzey Osetya'nın Prigorodny rayonunda meydana geldi. Çatışma aktif olarak 31 Ekim'den 6 Kasım'a kadar sürdü. Rusya Federasyonu Savcılığı'na göre, (bu konudaki İnguş istatistikleri farklıdır) her iki taraftan 583 kişi öldü, 939 kişi yaralandı, 261 kişi kayboldu ve 1093 kişi kaçırıldı (Dulayev \& Savin, 2012).

1992 Ekim ayında şiddet ortaya çıktığı sırada Kuzey Osetya'daki üçüncü büyük etnik grup 35.300 kişi (\% 5.2) ile İnguşlardı. Çatışma başladığında başkent Vladikavkaz ve Prigorodnıy'deki bütün İnguş nüfus (30.000) Kuzey Osetya'ya kaçtı. Rus askeri tarafından desteklenen Oset birimleri İnguşları sınır dışı etti (Bugajski, 2014: 35).

Prigorodnıy çatışmaları, en azından kısa vadede, Oset tarafının kesin bir zaferiyle sonuçlandı. Bu savaş ender görülen bir toprak çatışmasıdır. Bütün dünyada ve Sovyet sonrası dönemde geniş olarak kabul edilen sınırların kutsallı̆ı algısı dikkate alınacak olursa, Kuzey Osetya için sınırları üzerinde herhangi bir değişikliği kabul etmesi için pragmatik bir neden yoktur. Özellikle Rusya'nın Kuzey Osetya'nın arkasında olması bu nedenledir ve etnik grupların tavrı hiç olmadığı kadar uzlaşmazlık içindedir (Cornell, 2001: 250). Günümüzde Kuzey Osetyalı yetkililer ve bir dereceye kadar İnguş yetkililer çatışmanın mevcut olmadığını iddia etseler de bazı Oset ve İnguş siyaset bilimci ve tarihçilere göre Prigorodnıy rayonunun statüsü üzerindeki anlaşmazlık henüz çözülmüş değildir. Esasında Prigorodnı'ın 
ekonomik veya siyasi anlamda çok önemli bir konumu da yoktur, o bir semboldür. İnguşlar için tarihsel bir değer, Osetler için ise elde edilmiş bir kazançtır (Dulayev \& Savin, 2012). Etnisite, Kuzey Osetyalılar için iki işlevi yerine getirir. Birincisi kimlik belirtisidir. ikincisi ise doğudaki komşuları İnguşlara karşı bir savunma mekanizmasıdır. "Biz" ve "onlar" ikilemi bu bağlamda önemli bir uçurumu gösterir. "Onlar" kelimesi doğudaki komşuları için kullanılarak kimliksizleştirilir. Genelde uzmanlara ve konu ile ilgili kanaat önderlerine göre, Kuzey Osetya'da etnik gruplar arasındaki ilişkiler çok istikrarlıdır, ancak buna İnguşlar dahil değildir (Dulayev \& Savin, 2012).

\section{Kabardey-Balkar Cumhuriyeti}

Kabardey-Balkar, Rusya Federasyonu ölçeğinde, düşük gelir seviyesine ve yaşam standartlarına sahip olup ciddi yolsuzluk iddiaları olan ve ekonomisi büyük oranda federal merkezden gelen yardımlarla dönen özerk bir cumhuriyettir. Yaklaşık 900.000 olan cumhuriyet nüfusunun \%57'si Kabardey Çerkesleri, \%22.5'u Ruslar ve \%12.7'si Balkarlardan oluşmaktadır. Geri kalan nüfus içerisinde Türkler, Ermeniler, Osetler ve Çeçenler vardır.

Her ne kadar Rus yönetimi tarafından tahrif edildiği iddiaları olmasına rağmen, 2010 nüfus sayımına göre Rusya Federasyonu'nun toplam nüfusu yaklaşık 143 milyon iken; Çerkeslerin bu nüfus içindeki sayısı yaklaşık 720 bindir ve toplam nüfus içindeki payı \% $0.5^{\prime}$ dir. Rusya sınırları içinde en kalabalık Çerkes nüfus Kabardey-Balkar'da (yaklaşık 500 bin) yaşamaktadır (www.infocherkessia.com/cerkesnufus, 2014). Ancak yukarıda da belirtildiği gibi istatistiki verilerin yetersiz ve kalitesiz olması Kuzey Kafkasya'daki durumun gerçek boyutunun belirlenmesi ve anlaşılması için yeterli değildir. Rus İstatistik Servisinin hatalarla baş edemediği bilinen bir gerçektir. Örneğin 2010 ulusal nüfus sayımı sonuçları, nüfusun etnik bileşimi hakkındaki bilgileri tahrif etmiştir (Panin \& Tikunov, 2015: 80).

Kafkasya'nın ortası ve batısında iki grup halk yaşamaktadır. Bunlardan ilki Rusya devlet sisteminde resmi olarak Adıgeyliler (adıgeytsı), Kabardeyler (kabardintsı) ve Çerkesler (çerkesı) olarak tanımlanan otokton Çerkeslerdir. İkinci grup ise, Kuzey Kafkasya'nın yüksek vadilerinde yaşayan Karaçay ve Balkarlardır. Bunlar 13. 
yüzyılda Kafkasya'ya gelmişlerdir ve toplam sayıları 300 bin civarındadır. Bu iki grup, yani Çerkesler ve Karaçaylar 1920'lerden bu yana Rusya Federasyonu içinde iki özerk birime ayrılmış olarak yaşamaktadırlar. İlginç olan husus bu bölünmenin etnik bölünmeyi de ortasından kesmesidir (Cornell, 2001: 253).

Karaçay-Balkarlar ile Çerkesler arasındaki ilişkiler, 15. yüzyıldan itibaren Çerkeslerde asiller ve avam sınıfının mevcut olması gerçeği ile çok dalgalı olmuştur. Aynı farklı durum dağ halkları ile ovalarda yaşayan halklar arasında vardır ki bu durum inguşlar ve Osetler arasında da gözlenebilir. Özellikle en gelişmiş Kafkas halklarından olan Kabardey Çerkesleri, köklü tarihleri ile Balkarları ilkel bulup hor görmektedir (Cornell, 2001:253).

1943 yılında, Balkarlar ve Karaçaylar Sovyet rejimi tarafından topluca Orta Asya'ya sürgüne gönderildiler. 1957'den sonra, diğer bazı Kafkas halkları gibi onların da yaşadıkları topraklara dönmelerine izin verildi. Bu dramatik nüfus hareketleri, etnik gruplar arasında bir istikrarsızlığı beraberinde getirdi ve fikir birliği oluşmasına engel oldu.

Kabardey-Balkar bir zamanlar bölgenin en istikrarlı cumhuriyeti iken, günümüzde etnik anlaşmazlıklarla karşı karşıyadır. Kabardey Çerkeslerinin politikada, ekonomik ve sosyal kurumlarda baskın rolü Balkarları kızdırmaktadır. Kabardey Çerkesleri ise, Balkarların kendi etnik topraklarını oluşturmak ve Kabardey-Balkar'dan ayrılmak için mümkün olduğunca daha fazla toprak elde etmek için çalıştıklarını iddia etmektedirler. 1990'lardan itibaren Rusya dışından bu topraklara yapılan Kabardey göçü, Kabardey Çerkeslerinin nüfus içerisindeki çoğunluğunu arttırdı ve değişen demografik yapı Balkarları endişelendirirken, Çerkes milliyetçileri Rusya'dan daha fazla özerklik istedi (Bugajski, 2014: 33). Balkar milliyetçileri, bağımsız Çerkesya talepleri ve Çerkes milliyetçiliğinin yükselişi konusunda korkularını ifade etmektedirler.

Cumhuriyetler arasındaki sınırların yeniden çizilmesi bölgede tartışılmaya devam ederken, mevcut suni cumhuriyetler yerine Birleşik Çerkesya ve Birleşik Karaçay-Balkar cumhuriyetleri oluşturulması, bölgedeki etnik çeşitlilikten dolayı demografik bir zorluk yaratabilir ve kapsamlı nüfus değişikliklerini zorunlu kılabilir. Bu da etnik gerilim ve çatışmayı da beraberinde getirebilir.

\section{Dağıstan Cumhuriyeti}


Dağıstan, Kuzey Kafkasya'da en karmaşık etnik yapıya sahip cumhuriyettir. 2010 yılı itibariyle 2.910.000 nüfusa sahiptir. Ancak hiçbir etnik grubun demografik hegemonyası söz konusu değildir. Avarlar 850.000 (\% 29.4), Dargiler 490.000 (\% 17), Kumuklar 431.000 (\% 15), Lezgiler 385.000 (\% 13.2), Laklar 161.000 (\% 5.6), Tabasaranlar 118.000 (\% 4.1) Bölgede Ruslar, Çeçenler, Nogaylar dahil olmak üzere otuzu aşkın etnik unsur yaşamaktadır.

Dağıstan, iki lider etnik grup Avarlar ve Dargiler arasındaki rekabet dahil olmak üzere çok sayıda faktöre dayanan nedenlerle potansiyel istikrarsızlık vardır. Ayrıca, Avar ve Dargilerin hakimiyetine karşı diğer etnik topluluklar arasında kızgınlık, devlet sınırlarının böldüğü milletler nedeniyle bir gerilim mevcuttur. On dört etnik grubun Sovyet ve postSovyet sistemleri altında yönetime dahil olmaları, diğer bazı etnik gruplar arasında ulusal özerklik talepleri ve girişimlerinde bulunulmasına, bu da genel anlamda istikrarsızlığa yol açabilir. Çünkü, Dağıstan'da ana gruplar arasında devlet kademelerindeki önemli pozisyonların dağııııması konusunda yazıımamış sözleşmeler vardır. Üst elit grup üyeleri için, etnik farklılıklar yaratmak topluma hizmet etmek yolunda bir engel oluşturmaz, ancak kendi pozisyonlarını kaybetme tehdidi ile karşı karşıya kaldıklarında kendi etnik yakınlarını harekete geçirmektedirler(Matveeva, 2012). Bu yönüyle bakıldığında, Dağıstan, bütün Kafkasya bölgesinde olduğu gibi farklı ve çoğu zaman birbirine düşman etnik grupların bir araya geldikleri yerdir. Dolayısıyla, Avrupa'nın en tehlikeli yeri olarak adlandırımaktadır ve bunun da iyi bir nedeni de vardır (Wyman, 2014).

Milliyetlerin sayısı ve çakışan yerleşim kalıpları göz önüne alındığında, Dağıstan'da düzenli bir toprak bölünmesi imkansızdır. Ayrıca herhangi bir grup tarafından bu tür bir talebin dile getirilmesi zincirleme bir reaksiyona neden olabilir. Örneğin mağdur taraflar arasında yer alan Kumuklar yerel özerklik, daha radikal üyeleri ise Rusya bünyesinde bir cumhuriyet istemektedirler (Bugajski, 2014: 37). Aynı şekilde Dargiler da Dağıstan içinde ayrı bir vatan talep etmekte, buna karşılık Dağıstan yönetimi iç sınırların kalıcı olduğunu ifade ederek buna karşı çıkmaktadır. Avarlar ve Dargiler arasındaki pozisyonlar üzerindeki rekabet, diğer etnik gruplar arasında siyasi marjinalleşmeye yol açmaktadır.

$\mathrm{Bu}$ etnik gruplar arasındaki rekabet ve diğer nedenler bölgedeki 
şiddeti arttırmakta, bir çatışma potansiyeli oluşturmaktadır. Öyle ki 2013 yılında Kuzey Kafkasya'nın bütününde silahlı saldırı sonucu ölenlerin sayısı 529'dur ve 341'i Dağıstan'da gerçekleşmiştir. Rusya Güvenlik Konseyi başkanı Nikolay P. Patruşev Rusya'da şiddet olaylarında bir azalma olduğunu ifade etse de, 2013 yılında Rusya genelinde gerçekleşen 218 şiddet olayının 214'ünün Kuzey Kafkasya'da, bunların da çoğunluğunun Dağıstan'da olması Kuzey Kafkasya'nın ne denli bir gerginlik ve stres altında olduğunu göstermesi açısından dikkate değerdir (Halbach \& Isaeva, 2015: 5).

Yukarıda belirtilen bütün bu hususlar göz önünde bulundurulduğunda Dağıstan, gizli bir savaşın yürütüldüğü bir yer olarak kabul edilmektedir (Central Eurasia Standard, 2014). Bölgede hemen hemen her gün asayişle ilgili haberlere rastlamak mümkündür. Son zamanlarda sıkça yapıldığı gibi çatışmaları tamamıyla sadece İslam eksenli bir çatışma olarak görmek yüzeysel bir değerlendirme olacaktır.

Bütün bunların yanında, özellikle son yıllarda Çeçenlerin Dağıstan'da gerçekleştirdikleri faaliyetler de gerilim ve potansiyel bir çatışmaya kaynaklık edecek niteliktedir. Aslında her iki cumhuriyet etnik, kültürel ve tarihi gelişmeler bakımından yakındır. Dağıstan'ın batısındaki Hasavyurt şehri ve civarında yaklaşık 70.000 Çeçen yaşamaktadır. Rusların Kafkasya'yı ele geçirmek için ilk teşebbüsünden bu tarafa, Çeçenistan ve Dağıstan halkları en şiddetli direnişi göstermiş, en fazla Rus karşıtı ve bölgedeki en muhafazakar i̇slami milletler olmuştur. Bu halklar tarihte periyodik olarak Rus tahakkümüne karşı birlikte ayaklanmışlardır. Ve Dağıstan, bu isyanlarda hep ön planda olmuştur (Cornell, 2001:262). Dağıstan'ın Çeçen nüfusu, sadece önceki Çeçen topraklarına dönüş talebi değil, Dağıstan'dan ayrılarak yeniden "etnik vatan Çeçenistan"la birleşmeye hazırken; Çeçenistan'daki milliyetçi güçler Dağıstan topraklarında hak iddia etmektedirler. ÇeçenDağıstan sınırındaki temel gerilim, Çeçen köyü Borozdinovskaya ve Dağıstan kasabası Kızılyar arasında yatmaktadır. Son yıllarda köyde yaşayan Avar nüfus bölgeyi terk etmekte ve Kızılyar civarındaki bir kampta yaşamaktadır. Aynı durum Çeçenistan'ın diğer köylerinde söz konusudur ki, Dargiler bazı Çeçen köylerini (Dubovski) terk etmektedir. Köyde yaşayan ve evlerinden kovulma endişesi taşıyan ve etnik savaştan korkan birçok Avar, Dağıstan'ın iç bölgelerine göç etmiştir (Novitsky: 106). Bu gerilim ve çatışma ortamı Kuzey Kafkasya'da, 
özellikle Dağıstan ve Çeçenistan'da, insan hakları ihlallerini de beraberinde getirmektedir. Memorial İnsan Hakları Merkezi, son iki buçuk yılı kapsayan raporunda bölge yönetimlerinin insan haklarından ziyade güvenlik peşinde olduğu sonucuna vardığını açıklamıştır (Vatehagev, 2016).

30 Mayıs 2016 tarihinde Rusya Federasyonu Devlet Başkanlığı'na bağlı Rus İnsan Hakları Konseyi'nden bir heyet bütün Kuzey Kafkasya cumhuriyetlerini ziyaret maksadıyla çıktığı gezide sadece Çeçenistan devlet yetkililerince karşılanmamış, üstelik ülkeye girdikleri taktirde can güvenliklerinin garanti edilemeyeceği ifade edilmiştir. Rusya Federasyonu yetkililerinin Kadirov'un davranışı ile ilgili herhangi bir sorun görmemeleri, Mart 2016'da İşkenceyi Önleme Komisyonu Başkanı Kalyapin'in saldırıya uğraması ve faillerinin bulun(a)maması (Dzutsati, Chechnya's Gover...,2016), Çeçenistan'ın özellikle de Çeçen lider Kadirov'un Rus yönetimi tarafından korunduğu yönündeki kanaatleri güçlendirmektedir. Bu da Çeçen liderin Dağıstan'da ekonomik ve siyasal nüfuzunu arttırmasında elini güçlendirmektedir. Örneğin son zamanlarda Rus hükümetinin büyük boyutta özelleştirmeye gitmesi nedeniyle Mahaçkale limanına talip olan Rusya ve Dağıstan'ın önemli oligarklarından Avar asıllı Mogamedov ve Lezgi asıllı Süleyman Kerimov taraftarları arasında bir rekabet ortaya çıktı. Mahaçkale, Rus tahıl ve diğer tarım ürünlerinin Orta Doğu'ya ihraç edileceği yer ve aynı zamanda petrol ihracatı için önem taşıyan bir limandır. Ancak bu noktada Dağıstan ve Moskova oligarkları dışında beklenmedik bir oyuncu olarak Çeçen lider ortaya çıkarak, Gudermes'deki bir mahkemeye limanın CEO'sunun atanma kararını iptal eden bir karar aldırtmıştır. Kadirov'un bu müdahalesinin yabancı ülkelere Çeçen ilişkilerini genişletmek için Hazar Denizi kıyısında güvenli bir erişim merkezi oluşturma istemesi olarak yorumlanmaktadır (Dzutsati, 'Chechen Govern May....',2016). Basında çıkan haberlere göre Kerimov, liman üzerindeki konumunu korumak için Kadirov ile işbirliği yapmaktadır. Ancak Kadirov-Kerimov ittifakının ve liman üzerinde kontrol teşebbüsünün bir kıvılcıma neden olabileceği yönünde endişeler de vardır. Kadirov'un aktiviteleri ve kişisel ordusu, Mahaçkale limanı için yaşanan çatışmalar üzerinde belirleyici faktör olacaktır. 


\section{Sonuç}

Kuzey Kafkasya sadece Rusya Federasyonu içinde değil, dünyanın en önde gelen istikrarsızlık ve potansiyel çatışma alanlarından biridir. Rusya Federasyonu'nun güneydeki Orta Doğu ve Akdeniz havzalarına ulaşmasının tek yolu Kafkasya'dan geçmektedir. Bu nedenle de Rusya, bu bölge üzerindeki egemenliğini ve hakimiyetini korumak için mücadele verirken, küresel ve bölgesel rakipleri bölgeye nüfuz etme faaliyetlerini yoğunlaştırmışlardır. Bölgenin, çok çeşitli siyasi istikrarsızlıkların ve silahlı çatışmaların yaşandığı Orta Doğu ve Orta Asya ile sınırdaş olması ve Hazar havzasındaki doğal gaz ve petrollerin, alıcı ülkelere ulaştırılmasındaki stratejik konumu nedeniyle özellikle Güney Kafkasya bölgesi stratejik anlamda öne çıkmaktadır. Bu bölgede örneğin Gürcistan Batı dünyasına yakınlaşmaktayken Ermenistan ve Azerbaycan Batı dünyası ve Rusya arasında denge siyaseti sürdürmeyi tercih etmektedir. Bağımsız devletler olan Gürcistan, Azerbaycan ve Ermenistan'da yaşanan her siyasi ve askeri gelişme, Rusya Federasyonu'na bağlı özerk cumhuriyetleri de direk etkilemektedir.

Bunun yanı sıra, başta Türkiye olmak üzere Suriye, Ürdün, Batı Avrupa ve Amerika Birleşik Devletleri'nde bulunan Çerkes, Çeçen ve Abhaz diasporaları son yirmi yılda ciddi siyasi aktörler haline gelerek, Kuzey Kafkasya'da yaşamaya devam eden toplumlarının sosyal, siyasi ve ekonomik geleceklerinde önemli söz sahibi olmaktadırlar. Aynı şeyi Ermeni ve Azeri diasporaları için de söylemek mümkündür. Ayrıca, gerek Kuzey Kafkasya'da gerekse de Kafkas diasporalarında yükselen milliyetçiliğinin ve global anlamda dünyanın bölgeye artan ilgisinin önümüzdeki yıllarda gerilimin kaynağını oluşturacağı da dile getirilmektedir. Tüm bu faktörler, bölgenin küresel siyasetin önemli odaklarından birisi olma özelliğini pekiştirmektedir.

Ayrıca son yıllarda Rusya'daki sivil toplum örgütü sayı ve faaliyetlerindeki artışı da dikkatle izlemek gerekmektedir. Burada sözünü ettiğimiz artışı demokrasinin çoğulculuk ilkesiyle bağdaştırmak mümkün olmakla birlikte, etnik grupları mobilize etmek suretiyle bölgede bir etki alanı yaratmak amacı taşıdıkları yönündeki bir argümanları da göz önünde bulundurmak sağlıklı olur. 


\section{KAYNAKÇA}

Akusba, Erol (1998). "Kafkasya'da Etnik Sorunlar", Kafkas Vakıf Bülteni, Kış 1998, Sayı: 3.

Askerov, Ali (2015). Historical Dictionary of the Chechen Conflict, Maryland.

Bugajski, J. (2014). “Conflict Zones: The North Caucasus and Western Balkans Compared", The Jamestown Foundation, Washington.

Central Eurasia Standard (2014). "A guide to Conflict in the North Caucasus", 2 February. (Bu yazıya https://cestandard.wordpress.com /2014/02/11/ a-guide-to-conflict-in-the-north-caucasus adresinden ulaşılabilir).

Coene, F. (2010). The Caucasus: An Introduction, Routledge, London and New York.

Cornell, E. S. (2001). Small Nations and Great Powers: A Study of Ethnopolicial Conflict in the Caucasus, Routledge, London \& New York.

Dudloy, J. (2012). North Ossetia: Russia's Periphery, January. (Bu yazıya russiasperiphery.blogs.vm.edu. adresinden ulaşılabilir).

Dulayev, I. \& Savin, I. (2012). "What Next for North OssetiaComplications or Stability", in The North Caucasus: views from within. People's perspectives on peace and security, Saferworld Report, March.

Dzutsati, V. (2016). "Chechen Government May Be Winner in Dispute Between Dagestani Oligarchs", Eurasia Daily Monitor, Volume: 13, Issue:110, 20 June.

(2016). “Chechnya's Governor Confirm His Special Status Within the Russian Federation", Eurasia Daily Monitor, Volume:13, Issue:105, 13 June.

(2016). "Circassians Propose New Independent CrossRegional Groups in the North Caucasus", Eurasia Daily Monitor, Volume:13, Issue: 60, 28 March.

(2016). "Moscow Uses Russian Orthodox to Divide Circassian Activists", Eurasia Daily Monitor, Volume: 13, Issue: 97, 18 May. (2013). "Karachay Expert Supports Redrawing Borders in the North Caucasus", Eurasia Daily Monitor, Volume: 10, Issue: 37, 27 February. (Yazar bu makalesinde Dzutsev soyadını kullanmıştır)

Foxal, A. (2013). "Mapping Ethnic Relations, Cartography and Conflict Management in the North Caucasus", in Conflict and Peace in Eurasia, Debidatta Aurobinda Mahapatra (ed.), Routledge, London and New York.

Goble, P. (2015). “Ethnic Russians Flee North Caucasus Because They Do Not Feel Presence of Russian State", Jamestown Foundation Blog on Russia and Eurasia, 19 March. (Bu yazıya http://jamestownfoundation. blogspot.com.tr/2015_03_01_archive.html adresinden ulaşılabilir). 
(2015). "Non-Russian Are Following Ehnic Russians Out of The North Caucasus", Jamestown Foundation Blog on Russia and Eurasia, 29 September. (Bu yazıya http://jamestownfoundation.blogspot.com.tr/ 2015/09/non-russians-are-following-ethnic.html adresinden ulaşılabilir).

Grebennikov, M. (2015). "How Far is too Far?: Circassian Ethnic Mobilization and the redrawing of Internal Borders in the North Caucasus", Communist and Post-Communist Studies, Vol: 48. No: 1, 71-81.

Guseynov, A. R. (1996). "Ethnic Situation in the Caucasus", Center for Strategic Research Reports, September-November Issue. (Bu makaleye sam.gov.tr/wp-content/Uploads/2012/01/06-ETHNIC-SITUATION-IN-THE-

CAUCASUS adresinden ulaşılabilir).

Halbach, U. \& Isaeva, M. (2015). “Dagestan: Russia's Most Trouble Some Republic Political and Religious on the "Mountains of Tongues", SWP Research Paper. Berlin

International Crisis Group Working to Prevent Conflict Wordwide (2012). The North Caucasus: The Challenges of Integration, Etnicity and Conflict, Moscow/Istanbul/Brussels.

Jansız, A. \& Hojaste, M. R. (2015). "Conflicts in the Caucasus Region and Its Effects on Regional Security Approach", Journal of Politics and Law, Vol: 8, No:1.

Khanna, P. (2011). Yeni Dünya Düzeni: Yeni Yükselen Güçler 21. Yüzyılda Dünyayı Nasıl Belirliyor?, Çev: Elif Nihan Akbaş, Pegasus Yayınları, İstanbul.

Koehn, J. (2011). "The North Caucasus Conflict and its Implications for Russia", Event Report, Wilson Center, 7 July. (Bu dökümana https://www.wilsoncenter.org/event/the-north-caucasus-conflict-and-itsimplications-for-russia adresinden ulaşılabilir).

Liono, A. (2000). "Economic Survival Strategies in the North Caucasus", Caucasian Regional Studies, Volume: 5 Issue: 1\&2. (Makaleye Poli.vub.ac.be/publi/crs/eng/vol 5/lionu2.htm. adresinden ulaşılabilir).

Margaritis, C. (2010). "Conflict in the Caucasus", Res Publica-Journal of Undergraduate Research, Volume:15, İssue:1.

Markedonov, S. (2013). "The North Caucasus: The Value and Costs for Russia", Global Affairs, 20 December. (Makaleye eng.globalaffairs.ru/ number/The-North-Caucasus-The-Value-and-Costs-for-Russia adresinden ulaşılabilir).

Matveeva, A. (2012). "North Caucasus: Views From Within People's Perspectives on Peace and Security. Saferworld Report, London.

Minority Rights Group International (2014). World Directory of Minorities, 19 February.

Nichol, J. (2010). "Stability in Russia's Chechnya and Other Regions of the North Caucasus: Recent Developments", Congressional Research 
Service, December.

Novitsky, I. (2011) "Managing Ethnic Policy of The North Caucasus". Falcogroup. Krasnodar. (Bu raporun Ingilizce ve Rusça versiyonlarına http://falcogroup.org adresinden ulaşılabilir).

Panin, N. A. \& Tikunov, S. V. (2015). "Ethnic 'Barometer': EtnoDemographic and Migration Processes in the North Caucasus", J. Geogr. Inst. Cvijic. 65(1):77-89. (www. ebscohost. com www.gi.sanu.ac.rs, www.doiserbia.nb.rs adreslerinden ulaşılabilir).

Rezvani, B. (2010). "The Ossetian-Ingush Confrontation: Explaining a Horizontal Conflict", Iran and the Caucasus. Volume: 14, No: 2, 419-430.

Richmond, W. (2008). The Nortwest Caucasus: Past, Present, Future, Routledge, London \& New York.

Tekir, Osman (2011). "Potansiyel Bir Çatışma Alanı: Kuzey Kafkasya", Regional and Global Dynamics: Economic and Politicial Issues of Turkey and Its Near Abroad, International Symposıum, İzmir Üniversitesi, (e-book)

Vatehagev, M. (2016). “Disappearances in Dagestan Connected to Police Campaign Against Salafist", Eurasia Daily Monitor, Volume:13, Issue:109, June 17.

Infocherkessia. www.infocherkessia.com/cerkes-nufus, (2014) 20 Eylül.

Wyman, P. (2014). "A History of Violence: The North Caucasus and Mixed Martial Arts: Troubled Pipeline of Talent", www.bloodyelbow.com. (Erişim Tarihi:25.03.2016)

Yasa, I. (2008). "Kuzey Kafkasya'da Etnik Kompozisyon ve Çatışmalar", www.bilgesam.org., 5 Haziran. 